\title{
The Use of Social Media and Media Literacy during the Pandemic in Indonesia
}

\author{
Farida Win Sari Manurung ${ }^{1 *}$, Winning Amintas Kartika Waruwu ${ }^{2}$, Sukarman Purba ${ }^{3}$, \\ Lambok Pamancar Saragi ${ }^{4}$ \\ 1*SMK Negeri 1 Percut Sei Tuan, North Sumatra, Indonesia \\ ${ }^{2}$ AKPER Kesdam I/BB Medan, North Sumatra, Indonesia \\ ${ }^{3}$ Universitas Negeri Medan, North Sumatra, Indonesia \\ ${ }^{4}$ Education Agency of North Sumatra, Indonesia \\ Corresponding author: Farida Win Sari Manurung, faridamanurung39@gmail
}

\begin{abstract}
The COVID-19 pandemic has brought changes to nearly all aspects, including the aspect of economy and education. The use of social media has then increased during the pandemic for various purposes, such as for doing businesses and learning. However, many people have some constraints when using social media due to poor media literacy, limited knowledge in information and communication technology (ICT), lack of supporting facilities and infrastructure, and poor environmental condition. This study thus aims to describe the trends of social media use during the COVID-19 pandemic and how important digital literacy is to allow users to use social media wisely and carefully. The type of this research is literature review to presents theoretical frameworks to answer the research question.
\end{abstract}

Keyword: learning, the COVID-19 pandemic, online learning media, media online learning

\section{Introduction}

During the COVID-19 pandemic, nearly all aspects undergo changes, including the aspect of education. COVID-19 is a disease that attacks human respiratory tract with acute respiratory symptoms, such as fever, cough and shortness of breath. This disease is quickly transmitted to humans by droplets of saliva that come out of peoplewho been infected. Therefore, all physical interactions must be stopped temporarily and wearing masks becomes mandatory. Face-to-face learning should also be replaced with virtual learning to protect public health.

The use of social media has increased during the pandemic because people spend most of their time at home. Social media is also used for distance learning. However, many teachers find it difficult to utilize social media because of limited knowledge in information and communication technology (ICT), lack of supporting facilities and infrastructure, and poor environmental conditions. However, the learning still has to continue. There is no other option unless to adapt to changes.

According to Dabbagh and Ritland (2005), online learning is an open and distributed learning system by usingpedagogical tools or educational aids made possible via the internet and network-based technology to facilitate the formation of learning and knowledge processes through meaningful actions and interaction. 


\section{Method}

This is a literature study that willdescriptively analyze the trends of social media use during the COVID-19 pandemic in Indonesia.It aims to describe digital literacy, information society, social media, benefits and impacts of using media social, activities carried out using social media, and the importance of digital literacy for housewives.

\section{Results and Discussion}

The term 'digital literacy' has actually long emerged along with literacy media. It refers to an interest, attitudes, and individual abilities in using digital technology and tools communications to access, manage, integrate, analyze and evaluate information, build new knowledge, create and communicate with others so that can participate effectively in community (Potter, 2019). Since the number of internet users is increasing every year, media literacy becomes important.People with digital literacy skills continues to increase in number.

Social media users also increase in number. This is simply because social media provide many benefits for the users, such as free information, networking opportunities, entertainment and business opportunities for many people, including for housewives. According to Puntoadi (2011 in Purbohastuti, 2017), social media offer many advantages, such as personal branding. Various social media become a medium for people who communicate, discuss and even give a popularity. Social media provides opportunities that function interaction closer to consumers. Media social offers communication content more individual. Through the media social as well as various marketers can identify the habits of their consumers, make a personal interaction and build a deeper interest.

However, social media also have negative impacts on users if not used wisely. Fake news/hoaxes, pornography, fraud, scam, and many types of crimecan happen here. The use of social media is better when the users have some media literacy (Soecipto\&Holik, 2018).

\section{Conclusions}

It can be concluded that rapid media development should go hand-in-hand with digital literacy skills becausethey will bring some positive impacts on the lives of a community.One benefit that social media provide is the opportunity for doing businesses. It can help improve the family economy. Housewives should also be able to use social media wisely to obtain information and do businesses.

Not only are social media good for business, they are good for learning. Many social media, such as Google Classroom, Google Suite, Zoom, and WhatsApphave been very useful learning tools during the COVID-19 pandemic. Teachers can make an innovation in the ways that the materials are presented and delivered.

\section{References}

Dabbagh, N. \& Ritland. B. B. (2005). Online Learning, Concepts, Strategies and Application. Ohio: Pearson.

Potter, W.J. (2019). Media Literacy. $9^{\text {th }}$ Editon. Thousand Oaks. CA: Sage. 
Purbohastuti, A W. (2017). Efektivitas Media Sosial Sebagai Media Promosi. Tirtayas Ekonomita.12(2):212-231.

Soecipto, S. \& Abdul Holik. (2018). Pemanfaatan Media Sosial Bagi Ibu Rumah Tangga dan Pemuda di Desa Arjasari Kecamatan Arjasari Kabupaten Bandung. Jurnal Pengabdian Masyarakat. 8(1). Retrieved from https://www.maxmanroe.com/vid/teknologi/internet/pengertian-media-sosial.html. 